\title{
NOVELTIES ON THE DISTRIBUTION OF LEPECHINIA FLAMMEA (LAMIACEAE), ReDisCOVERY OF L. GLOMERATA IN JALISCO, MEXICO, AND THEIR PHYLOGENETIC POSITION WITHIN LEPECHINIA
}

\author{
Jesús Guadalupe González-Gallegos ${ }^{1,2,6}$, Bryan Drew⿳3,4 and Ramón Cuevas-Guzmán ${ }^{5}$ \\ ${ }^{1}$ Centro Interdisciplinario de Investigación para el Desarrollo Integral Regional (CIIDIR), \\ Instituto Politécnico Nacional, Durango, México \\ ${ }^{3}$ Cátedras CONACyT, México D.F., México \\ ${ }^{3}$ Department of Botany, University of Wisconsin, Madison, U.S.A. \\ ${ }^{4}$ Department of Biology, University of Florida, Gainesville, U.S.A. \\ ${ }^{5}$ Instituto Manantlán de Ecología y Conservación de la Biodiversidad, Universidad de Guadalajara, Jalisco, México \\ ${ }^{6}$ Corresponding author: xanergo@hotmail.com
}

\begin{abstract}
The recently described Lepechinia flammea was originally known only from the Sierra Madre del Sur in Guerrero, Mexico. However, a new population of this species was uncovered in Jalisco during recent botanical explorations. Additionally, it was more recently described in Oaxaca as L. oaxacana, a name that in this work is synonymized with L. flammea. Meanwhile, L. glomerata, the most morphologically similar species to L. flammea, was rediscovered in Jalisco. Morphological notes on L. flammea, an extended description of L. glomerata, and photographs and distribution maps for the two species are provided. We also explore the relationships of these two species within Lepechinia, and show they are closely related to the more broadly distributed L. nelsonii.
\end{abstract}

Keywords: disjunction, Lepechinia section Glomeratae, Sierra de El Cuale, western Mexico.

Resumen: La recién descrita Lepechinia flammea fue registrada originalmente solo de la Sierra Madre del Sur en Guerrero, México. Sin embargo, durante exploraciones botánicas recientes, una nueva población de esta especie fue descubierta en Jalisco. Por otra parte, fue descrita en Oaxaca como L. oaxacana, nombre que aquí se relega a sinonimia de L. flammea. Además, se redescubre en Jalisco a L. glomerata, la especie más similar en su morfología a L. flammea. Se proveen notas morfológicas de L. flammea, se amplía la descripción de L. glomerata, y se proporcionan fotografías y mapas de distribución de las especies. También se exploran las relaciones de ambas dentro de Lepechinia, además de mostrarse que están más relacionadas con L. nelsonii, una especie de mayor distribución.

Palabras clave: disyunción, Lepechinia section Glomeratae, occidente de México, Sierra de El Cuale.

$\mathbf{T}$ he genus Lepechinia Willd. contains about 45 species, and is composed of perennial herbs to large shrubs that generally possess aromatic leaves, paniculate or spiciform inflorescences, sessile to short pedicellate flowers, +/- actinomorphic to weakly 2-lipped calyces that are exannulate at the throat and usually accrescent in fruit, weakly 2-lipped corollas, four didynamous stamens (included to long-exserted), short and subequal stigmatic branches, an annulate corolla, and (as opposed to the closely related genera $\mathrm{Me}$ lissa L. and Salvia L.) non-mucilaginous mericarps (Harley et al., 2004). The taxonomic placement and the definition of the genus in terms of the species composition have been controversial (e.g., Epling, 1926; Hart, 1983; Drew, 2011). Drew and Sytsma (2011, 2013) and Drew et al. (2014) conducted phylogenetic analyses using DNA sequences from the nucleus and chloroplast to clarify this situation, and their results supported the placement of Lepechinia within tribe Mentheae, subtribe Salviinae, which is in concordance with the treatment of Harley et al. (2004). Additionally, Drew (2011) and Drew and Sytsma $(2011,2013)$ convincingly demonstrated that the Eurasian genus Melissa is sister to Lepechinia, and that Lepechinia was paraphyletic as traditionally 
circumscribed. The options that Drew and Sytsma (2011) proposed to render Lepechinia monophyletic were either: (1) segregate L. mexicana (S.Shauer) Epling [L. yecorana Henrickson, Fishbein \& T.Van Devender was not yet described], which was nested within a clade that included the monospecific genera Chaunostoma Donn.Sm. and Neoeplingia Ramamoorthy, Hiriart \& Medrano; or (2) transfer the two preceding taxa to Lepechinia. However, they suggested that the final decision should wait until more robust evidence (e.g., low copy nuclear genes) was procured. Nonetheless, Moon (2012) made the transfer of Chaunostoma mecistandrum Donn.Sm. to Lepechinia (L. mecistandra (Donn.Sm.) H.K.Moon), and subsequently Drew et al. (2014) transferred Neoeplingia to Lepechinia [L. leucophylloides (Ramamoorthy, Hiriart \& Medrano) B.T.Drew, Cacho \& Sytsma]. These results suggest that Salviinae should consist of Lepechinia, Salvia (sensu Walker and Sytsma, 2007), and Melissa (Walker and Sytsma, 2007; Drew and Sytsma, 2011, 2013), which was previously unplaced within Mentheae (Harley et al., 2004). Although there are no clear morphological synapomorphies that characterize Lepechinia, it can be distinguished from other members of Salviinae based on non-galeate upper corolla lips, an unenlarged connective separating the two thecae of the stamens (as opposed to most Salvia), non-mucilaginous mericarps, and a distinctive leaf odor. Among the diagnostic characters, only the latter one holds promise as a potential synapomorphy. However, it will be necessary to uncover the chemicals responsible for the distinctive odor before this possible synapomorphy can be validated. The other characters mentioned can be considered plesiomophic since they are extensively distributed in the family. Epling (1948) acknowledged the lack of synapomorphies for the genus, and instead argued that Lepechinia formed a cohesive lineage based on a "chain" of characters, with the remark that "The only consistent alternative to recognizing one genus...is to recognize eight".

Lepechinia is restricted to the New World with populations of some of its species [L. hastata (A.Gray) Epling in Hawai'i, and L. stellata (Cordem.) Epling in Réunion Island] probably being human introductions overseas (Hart, 1983; Drew and Sytsma, 2011). In Mexico there are 12 species, seven of which are endemic: L. leucophylloides (formerly Neoeplingia leucophylloides Ramamoorthy, Hiriart \& Medrano; Drew et al., 2014), L. flammea Mart.Gord. \& Lozada-Pérez, L. glomerata Epling, L. hastata, L. mexicana, L. nelsonii (Fernald) Epling, and L. yecorana Henrickson, Fishbein \& T.Van Devender (Martínez-Gordillo et al., 2013). Most of these taxa occupy temperate forests at high elevations, dwelling in pine-oak, oak, and/or montane cloud forests, though there are some exceptions such as $L$. mexicana and L. leucophylloides, which grow in more arid conditions.

Epling (1948) divided the genus into eight sections. Section Glomeratae Epling was defined to include only one species, Lepechinia glomerata. This section is distinctive within Lepechinia due to its sessile flowers arranged in hemispherical glomeruli, which are axillary and long pedunculed, and are subtended at the base by two showy floral bracts. Lepechinia glomerata was described based on specimens from a single collection [Mexia $1804(\mathrm{MICH}, \mathrm{UC}$, US); Epling, 1948], which was made at San Sebastián del Oeste, Jalisco, in 1927. Since the initial collection, no other specimens have been cited from the same area, even though a floristic survey was conducted and published for that region (Reynoso et al., 2006). In 2009, Martínez-Gordillo and Lozada-Pérez described L. flammea from Guerrero and placed it within Glomeratae since its characteristics matched well with the section definition and the apparent morphological similarity to L. glomerata. In fact, several specimens of L. flammea were initially determined to be L. glomerata. In the same publication, a specimen of L. glomerata was cited from the state of Guerrero, being the second citation of the species; however, it was collected about $600 \mathrm{~km} \mathrm{SE}$ of the type locality. As part of a broad examination of Lepechinia, Drew (2011) demonstrated a close relationship between L. flammea (labeled as L. glomerata in that publication) and L. nelsonii, and included both of these taxa as part of a redefined section Eulepechinia Epling, a clade that included all Lepechinia taxa (but not Chaunostoma or Neoeplingia) native to Mexico (except L. mexicana) and three South American taxa. Turner (2013) added a new species, L. oaxacana B.L.Turner, that he considered closely allied to L. flammea and L. glomerata. This new species description was based on a single collection and single specimen [I. Trujillo-Olazo 1336 (TEX)].

Ongoing studies of Lamiaceae have necessitated numerous botanical expeditions and the examination of herbarium specimens at several herbaria. These efforts have provided new insights on the distribution and morphological variation of several species. Here we report on new findings of Lepechinia flammea, as well as new populations of the poorly collected $L$. glomerata. We also assess the validity of the recently described $L$. oaxacana. In addition, we employ three chloroplast markers and four nuclear markers to examine the phylogenetic affinities of L. flammea and L. glomerata within Lepechinia.

\section{Material and methods}

Morphological conspectus. The morphological notes on Lepechinia flammea (including L. oaxacana) and the extended description of $L$. glomerata were based on examinations of herbarium specimens held in the following herbaria, with acronyms according to the Index Herbariorum (Thiers, 2014): ENCB, FCME, IBUG, IEB, MEXU, MICH, UAGC, UC, WIS, and ZEA; and online pictures deposited on the webpages of TEX and US herbaria. The specimens collected from the botanical explorations, which led to the disco- 
very of the new populations of both species in Jalisco, were processed according to standard procedures (e.g., Lot and Chiang, 1986; Sánchez-González and González, 2007). A complete specimen set was deposited in the IBUG and ZEA herbaria.

Taxon and gene sampling, DNA extraction, and sequencing. Two accessions of Lepechinia, L. glomerata and L. nelsonii, were added to the data matrices from Drew and Sytsma (2013), for a total of 33 Lepechinia accessions (Appendix 1). Although Drew (2011) and Drew and Sytsma (2011, 2013) included an accession labeled as L. glomerata ( $B$. Drew 155), their sample was actually L. flammea (Martínez-Gordillo and Lozada-Pérez, 2009). Lepechinia nelsonii was included because Drew (2011) showed this species was allied to L. flammea. Melissa officinalis L. was chosen as outgroup based on Walker and Sytsma (2007), and Drew and Sytsma (2011, 2013). Our dataset consisted of three chloroplast (cpDNA; $y c f 1, y c f 1$-rps 15 spacer, and the $\operatorname{trnL}$ $F$ spacer and intron) regions, the internal and external transcribed spacers (ITS and ETS, respectively), and two lowcopy nuclear gene regions (granule-bound starch synthase I (GBSSI or waxy) and a pentatricopeptide repeat gene region (PPR-AT3G09060). DNA extractions, PCR reactions, and cycle sequencing procedures were as described within Drew and Sytsma (2013).

Phylogenetic analyses. Chromatograms from all gene regions were examined and manually edited in Sequencher 4.7 (Gene Codes, Michigan, USA), and subsequently aligned in MacClade 4.08 (Maddison and Maddison, 2005). Sequence polymorphisms as inferred by chromatogram double peaks were scored as polymorphic characters. The cpDNA and the four nuclear gene region (nDNA) data sets were analyzed using Maximum Likelihood (ML) in Garli 2.0 (Zwickl, 2006) and Maximum Parsimony (MP) in PAUP 4.0b10 (Swofford, 2002). The ML analyses were implemented using the default configuration parameters (with 3 searchreps) and the GTR $+\Gamma+$ I model of evolution. To assess the support for the ML analyses we performed 100 bootstrap (BS) repetitions using the same configuration as the initial ML search, with the exception that only one search (searchreps $=1$ ) was done per BS replicate. The MP analyses were conducted by sampling 1,000 random addition replicates with TBR branch swapping and Multrees On. Bootstrap (Felsenstein, 1985) values were obtained by performing 100 heuristic searches, sampling 100 random addition replicates per search, and otherwise using the same settings as the initial best tree(s) search.

\section{Results}

Morphological conspectus

Lepechinia flammea Mart.Gord. \& Lozada-Pérez, Brittonia
61:112-115. 2009. Type: Mexico. Guerrero. Malinaltepec: al N de Tres Marías, 17 7' 42" N, 98 41' 16.8” O, 2,500 m, 21 Nov 2005, L. Lozada P. 2964 (holotype FCME). L. oaxacana B.L.Turner, Phytologia 95:138-140. 2013. Type: Mexico. Oaxaca. Distrito Sola de Vega. Santiago Textitlán: paraje abajo de El Portillo, $16^{\circ} 43^{\prime} 58.2^{\prime \prime} \mathrm{N}, 97^{\circ} 25^{\prime} 10.3^{\prime \prime}$ W, 1,190 m, 8 Jan 2007, I. Trujillo-Olazo 1336 (holotype TEX).

A new population of Lepechinia flammea was discovered in the middle of the mountain range known as El Cuale in the state of Jalisco, at the westernmost extreme of the Trans-Mexican Volcanic Belt, on the west side of San Pedro Mountain (Figure 1). The population dwells in ecotones of pine-oak and pine-fir forests, between 2,430 and 2,480 m elevation. It shares habitat with Abies flinckii Rushforth, Alnus jorullensis Kunth, Arbutus xalapensis Kunth, Carpinus caroliniana Walter, Clethra fragrans L.M.González \& R.Delgad., C. hartwegii Britton, Cornus disciflora Moc. \& Sessé ex DC., Desmodium sumichrastii (Schindl.) Standl., Garrya laurifolia Hartweg ex Benth., Litsea glaucescens Kunth, Pinus herrerae Martínez, P. pseudostrobus Lindl., P. strobiformis Engelm., Quercus castanea Née, Q. laurina Humb. \& Bonpl., Q. scytophylla Liebm., Rumfordia floribunda DC., Styrax ramirezii Greenm., Symplocos citrea Lex., and Ternstroemia lineata DC. Other labiates occurring at the site include Clinopodium macrostemum (Moc. \& Sessé ex Benth.) Kuntze, Salvia elegans Vahl, S. gesneriiflora Lindl. \& J.Paxton, S. iodantha Fernald, S. lavanduloides Kunth, and S. quercetorum Epling. Lepechinia flammea has been collected in flower and fruit from February to May.

The qualitative morphological characters of the Lepechinia flammea population in Jalisco correspond well with those described by Martínez-Gordillo and Lozada-Pérez (2009). There are some quantitative morphological features that differ from the parameters outlined by Martínez-Gordillo and Lozada-Pérez (2009), however, and these are highlighted in the following lines. The size of the leaves of the middle of the stem vary from $12.7-23 \mathrm{~cm}$ long, and $2.7-4.4 \mathrm{~cm}$ wide at mid-leaf, and are progressively reduced towards the apex of the plant; just below the inflorescence the leaves diminish to $2.1-5.6 \times 0.9-1.5 \mathrm{~cm}$. The inflorescences are $13-30 \mathrm{~cm}$ long, with peduncles $1.9-4.5 \mathrm{~cm}$ long (in the original description, peduncle length was registered as 1.4-5.1 mm, instead of $\mathrm{cm}$, probably because of a typographical mistake). The external floral bracts can reach up to $1.4 \mathrm{~cm}$ wide, the width of the bracteoles (internal bracts) ranges from 1.9-5.5 $\mathrm{mm}$. Each glomerulus consists of 7-10 flowers with pedicels 0.8$2.3 \mathrm{~mm}$ long and corolla tubes $13-16.5 \mathrm{~mm}$ long. The thecae are up to $1.7 \mathrm{~mm}$ long and the mericarps are between (2.4-) $2.7-2.9 \times(1.6-) 1.8-2.2 \mathrm{~mm}$. The population from Jalisco is also within the altitudinal and phenological ranges of the populations from Guerrero, growing from 2,000 to 2,700 m, and flowering and fruiting from October to May, respectively (Martínez-Gordillo and Lozada-Pérez, 2009). 

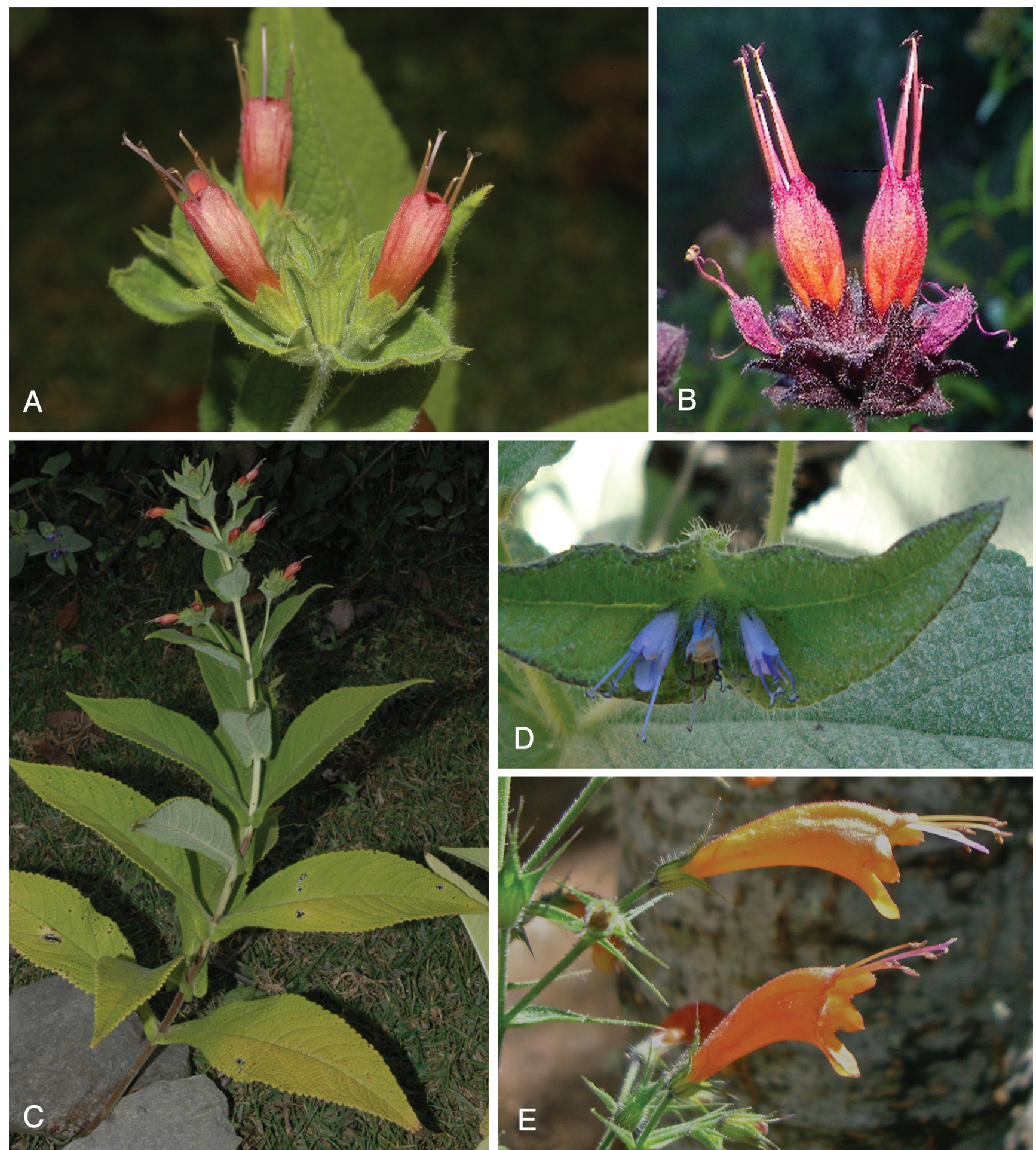

Figure 1. (A) Glomerulus with green floral bracts and calyces of Lepechinia flammea and (B) one with purple floral bracts and calyces, (C) general aspect of L. flammea, (D) glomerulus of L. glomerata, and (E) portion of the panicle of L. nelsonii. Pictures A and C taken by B. Drew, B by A. Castro-Castro, and D and E by J.G. González-Gallegos).

When considering the morphological variation of Lepechinia flammea, the recognition of L. oaxacana as a different species is unjustified. Turner (2013) makes the distinction mainly based on smaller foliage $[6-10 \times 2-3 \mathrm{~cm} v s$. the 10 -
$20 \times 3-6 \mathrm{~cm}$, purportedly stated by Martínez-Gordillo and Lozada-Pérez (2009)], smaller calyces ( $c a .6$ mm vs. 9-11 $\mathrm{mm}$ long), and smaller corollas (10-12 × 3-4 mm vs. 16-20 $\times$ 6-8 mm). However, the leaves of L. flammea were described 
as $3.9-20 \times 1.5-6.3 \mathrm{~cm}$ by Martínez-Gordillo and LozadaPérez (2009); hence, it is not clear why Turner (2013) used a different variation range to contrast his species than the one written in the original description. Additionally, Turner (2013) did not clarify if the $c a .6 \mathrm{~mm}$ he reported for calyx length referred only to the calyx tube or to calyx tube plus the length of the lobes. In the holotype (the unique collection and specimen he examined) the calyces including the lobes reach up to $10 \mathrm{~mm}$ long, which lies within the range provided in the description of L. flammea. The corollas of L. flammea are indeed described as $16-20 \mathrm{~mm}$ long, but no mention of corolla width is made by Martínez-Gordillo and LozadaPérez (2009); the corollas in the holotype of L. oaxacana are up to $15 \mathrm{~mm}$ long. Moreover, the holotype specimen of L. oaxacana is not well preserved; the leaves are crumpled, withered and broken, as are some of the corollas. In summary, the overlap of morphological variation between the taxa, uncertainty of measurements given in the description of $L$. oaxacana, and the fact that this species was described based upon a single collection of poor quality, lead us to regard $L$. oaxacana as a synonym of L. flammea. Unfortunately, leaf tissue of L. oaxacana was not available for DNA extraction, but we consider the morphological evidence quite clear and convincing.

Specimens examined: Mexico. Guerrero. Atoyac de Álvarez: $15 \mathrm{~km}$ al NE de El Paraíso, 1,100 m, 25 May 1986, J.C. Soto-N. \& F. Solórzano-G. 12829 (MEXU). Chihihualco: $26 \mathrm{~km}$ al SE de Filo de Caballo, camino a Puerto del Gallo, 2,000 m, 18 Oct 1983, E. Martínez-S. et al. 4933 (MEXU); $2 \mathrm{~km}$ al NE de El Jilguero, camino Atoyac-Filo de Caballo, 2,250 m, 23 Nov 1983, E. Martínez-S. \& F. Barrie 5682 (MEXU); $24 \mathrm{~km}$ al SE de la Hierbabuena, sobre el camino a Filo de Caballo, Puerto del Gallo, 2,330 m, 26 Feb 1984, E. Martínez-S. et al. 6163 (MEXU); Puerto El Jilguero, 2,560 m, 15 Dec 1985, J.C. Soto-N. 11829 (MEXU); 2.2 km NE of El Jilguero, along road from Filo de Caballo to Puerto del Gallo, $17^{\circ} 30^{\prime} 3.38^{\prime \prime} \mathrm{N}, 100^{\circ} 0$ ' 37.69” W, 2,480 m, 17 Jan 2008, B. Drew 155 (WIS). Malinaltepec: Ojo de Agua de Cuauhtémoc, 26 Dec 2012, E. Cándido-B. \& B. Nepomuceno-C. 117 (IBUG, UAGC). Jalisco. Talpa de Allende: parte Alta de la Mina de El Cuale, $20^{\circ} 21^{\prime} 14^{\prime \prime} \mathrm{N}, 105^{\circ} 0$ ' 24.6" O, 2,435 m, 1 May 2003, R. Cuevas-G. et al. 7743 (IBUG, ZEA); $30 \mathrm{~km}$ por la brecha de Talpa de Allende rumbo a El Cuale, extremo O del cerro San Pedro, $5 \mathrm{~km}$ al SO de la Tetilla de El Cuale, $20^{\circ} 21$ ' 30.82 " N, $104{ }^{\circ}$ 59' 56.22” O, 2,470 m, 4 Feb 2013, J.G. González-Gallegos et al. 1468 (IBUG); $30 \mathrm{~km}$ por la brecha de Talpa de Allende rumbo a El Cuale, extremo O del cerro San Pedro, $5 \mathrm{~km}$ al SO de la Tetilla de El Cuale, $20^{\circ} 21$ '23.77" N $105^{\circ} 0.69^{\prime} 41.89$ " O, 2,481 m, 18 Mar 2013, J.G. González-Gallegos et al. 1495 (IBUG). Oaxaca. Santiago Textitlán: paraje debajo de El Portillo, $16^{\circ} 43^{\prime} 58.2^{\prime \prime} \mathrm{N}, 97^{\circ} 25^{\prime} 10.3$ ” O, 1,190 m, 8 Jan 2007, I. Trujillo-O. 1336 (TEX) (Figure 2).
Lepechinia glomerata Epling, Brittonia 6:356. Type: Mexico. Jalisco. San Sebastián del Oeste: Hacienda del Ototal, 4 Mar 1927, Y. Mexia 1804 (holotype UC, isotype MICH, US).

Lepechinia glomerata had not been collected for several decades following the first collection, which was gathered in 1927. During 2002 and 2011, independent explorations in Sierra de El Cuale, Jalisco, led to the discovery of populations of the species along a dirt road from about $4 \mathrm{~km} \mathrm{~N}$ of El Tuito to Minas de Zimapán, in the municipality of Cabo Corrientes. Later, while consulting herbarium collections, another specimen was encountered at the $\mathrm{MICH}$ herbarium; a collection made by Rogers McVaugh from the same area in 1975. The species was also documented in the municipality of Tecpan de Galeana, Guerrero (Martínez-Gordillo and Lozada-Pérez, 2009), with a collection made in 2007. In contrast, a botanical excursion in 2009 to the type locality did not yield individuals of the species. Thus, 48 years passed since the species was collected for the first time until the next series of collections. On the basis of these recent specimens and the paucity of historical collections, an extended description is provided.

Shrub (0.7-)1.6-2(3) m tall, stems hirsute, puberulent, and covered with short glandular-capitate hairs. Leaves sessile, leaf blades lanceolate to slightly elliptic-lanceolate, (3.7-)6.3-20 × (1.3-)2-3.9(-8.1) cm, acute at the apex, auriculate and amplexicaul at the base, margins serrate chiefly on the biggest leaves. Leaves sparsely pilose and puberulent, occasionally with some glandular-capitate hairs, the indumentum concentrated along the veins and beneath them, young leaves bullate above, very aromatic, progressively diminishing in size toward the apex. Flowers 8-14, arranged in capituliform inflorescences (glomeruli), attached in the axils of reduced leaves. Peduncles 3.2-4.8 cm long, hirsute and with glandular-capitate hairs. Floral bracts of the same shape, texture, and color than the leaves, but smaller (1.5-

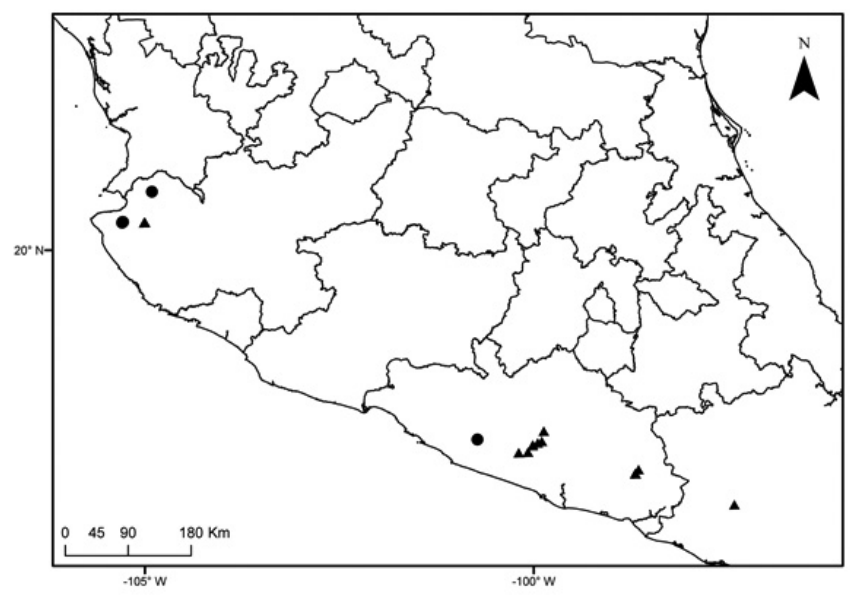

Figure 2. Distribution map of Lepechinia flammea (triangles) and L. glomerata (dots). 
$2.9 \times 0.6-1.1 \mathrm{~cm}$ ), sparsely pilose, puberulent and bordered by glandular-capitate hairs. Bracteoles lanceolate to linearlanceolate, 0.5-0.8(-1.1) cm long, membranaceous, sparsely pilose and ciliated at the margin, which is entire. Flowers with pedicels $0.8-1.3 \mathrm{~mm}$ long, pilose and with sessile glandular dots. Calyx green, tube 2.9-3.9 mm long, 3.2-3.5 mm wide at the throat, pilose and covered with glandular-capitate hairs and sessile glandular dots, teeth 1.9-2.5 mm long. Corolla light blue to lavender (lilac in the original description), glabrous, tube $6.8-7.8 \times 2.3-3.4 \mathrm{~mm}$, not constricted at the base, lobes subequal, 0.8-2.2 $\mathrm{mm}$ long. Stamens exserted, attached at 5.8-6.2 mm of corolla length from the base, filaments 8.4-8.9 mm long, glabrous, thecae 0.5-1 mm long. Style 1.1-1.4 cm long, branches subulate and subequal, 0.8-
$0.9 \mathrm{~mm}$ long. Mericarp ovoid, 2.5-2.9 × 1.7-2.1 mm, black to dark brown, smooth and glabrous.

Specimens examined: Mexico. Guerrero. Tecpan de Galeana: bajitos de La Laguna, Costa Grande, $17^{\circ} 34^{\prime} 3.7^{\prime \prime} \mathrm{N}$, $100^{\circ}$ 43' 29.6” O, 1,180 m, 15 Jan 2007, Y. Marcos-G. 512 (FCME); Jalisco. Cabo Corrientes: 3-10 km generally E on the road to Mina del Cuale, from the junction $5 \mathrm{~km} \mathrm{NW}$ of El Tuito, 850 m, 16 Feb 1975, R. McVaugh 26448 (MICH); km 3.4 de la brecha a la Mina de Zimapán, 20 21' 7' N, $105^{\circ} 17$ ' 42" O, 9 Mar 2002, P. Carrillo-R. \& E. SahagúnG. 3032 (IBUG); brecha El Tuito a la Mina de Zimapán, 5.3 $\mathrm{km}$ a partir de la carretera El Tuito a Puerto Vallarta, $1.3 \mathrm{~km}$ antes de llegar a la localidad de Provincia, 20 21' $38.2^{\prime \prime} \mathrm{N}$,

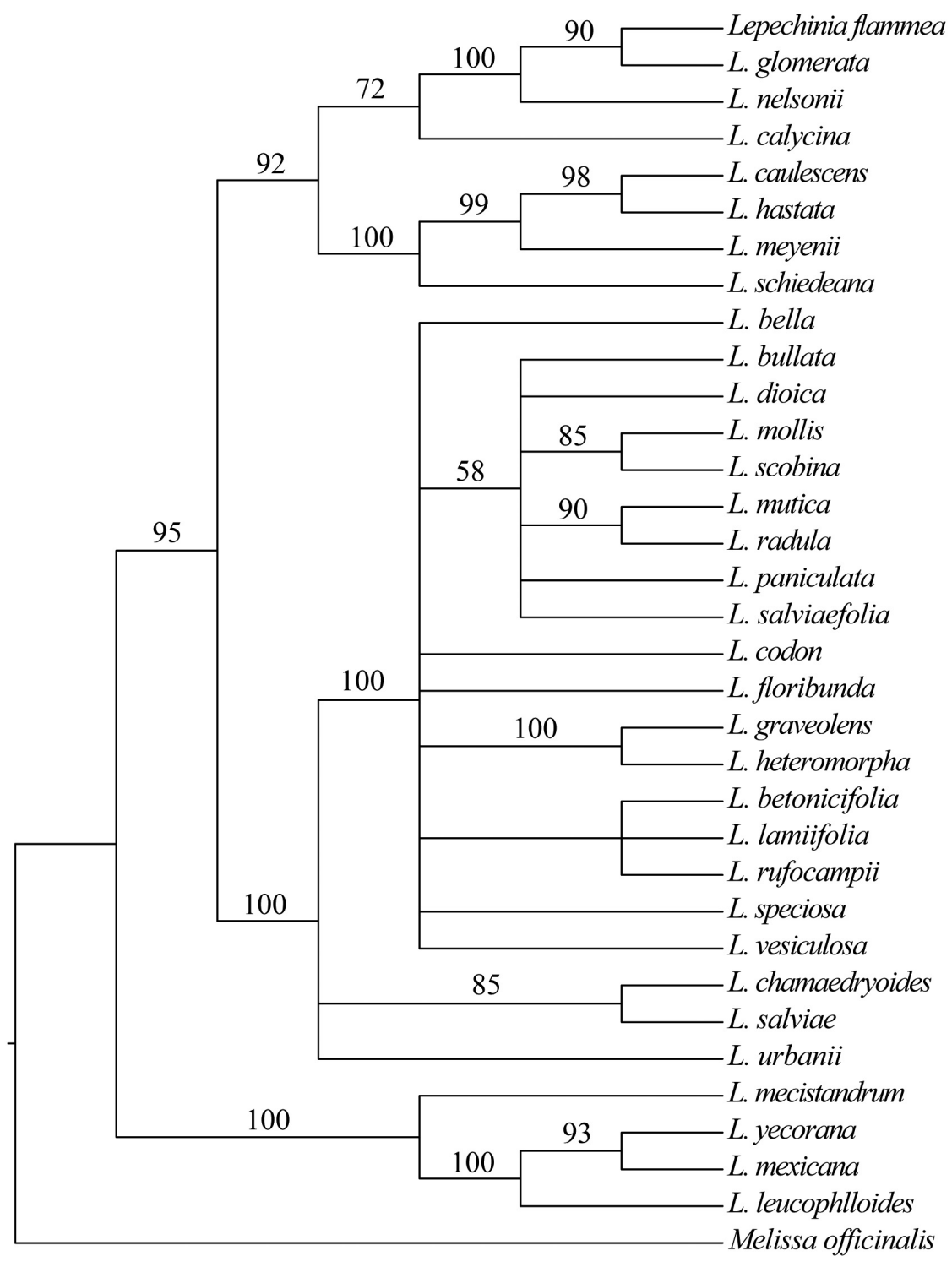

Figure 3. Maximum likelihood (ML) phylogram of Lepechinia as inferred from an analysis of three concatenated cpDNA gene regions ( $y c f 1, y c f 1$-rps 15 spacer, and trnL-F spacer and intron). ML and MP bootstrap values above 70\% are indicated near corresponding nodes. Focal taxa of this study are shown within box. 
105 16' 58.8” O, 924 m, 13 Mar 2011, J.G. González-G. et al. 947 (IBUG); $5.6 \mathrm{~km}$ por la brecha de El Tuito a Las Minas de Zimapán, a partir de $4 \mathrm{~km}$ al $\mathrm{N}$ de El Tuito, carretera a Puerto Vallarta, 20 21'34.29” N, 105'17'8.07' O, 962 m, 12 Aug 2011, J.G. González-G. et al. 1074 (IBUG).

Lepechinia glomerata inhabits oak-pine forests and ecotones of oak-pine/montane cloud forests from 850 to 1,180 $\mathrm{m}$ elevation. Its associates include Augusta rivalis (Benth.) J.H.Kirkbr., Byrsonima crassifolia (L.) Kunth, Calophyllum brasiliense Cambess., Cecropia obtusifolia Bertol., Inga andersonii McVaugh, Magnolia pacifica A.Vázquez, Oreopanax peltatus Linden, Podocarpus matudae Lundell, Quercus aristata Hook. \& Arn., Q. glaucescens Bonpl., and Q. salicifolia Née. It flowers and fructifies from January to March.

In addition to the characters that Martínez-Gordillo and Lozada-Pérez (2009) highlight in supporting the distinction between Lepechinia glomerata and L. flammea, the first species can also be differentiated by the shorter thecae $(0.5$ 1 vs. 1-1.5 mm long) and shorter style (1.1-1.4 vs 1.6-2 cm long) from the latter one.

Phylogenetic analyses. With the exception of the relationships involving the newly added Lepechinia glomerata and L. nelsonii accessions, the results obtained from the molecular datasets presented here have been discussed elsewhere (e.g., Drew and Sytsma, 2013), so only the phylogenetic relationships involving L. flammea, L. glomerata, and L. nelsonii will be reported here.

After examining the cpDNA and nDNA phylogenetic trees, it was obvious that significant discordance (see also Drew and Sytsma 2011, 2013; Drew et al., 2014) existed between the two datasets and no attempt was made to concatenate them. In both the cpDNA and nDNA, analyses the ML and MP topologies were congruent (i.e., no supported conflicts), therefore only the ML trees (with ML and MP BS values) are shown since they can more easily be displayed as phylograms and hence convey branch length information. The MP trees, however, are readily available upon request. The cpDNA dataset included 5,959 characters, of which 526 were variable and 194 were parsimony informative (PI; $3.3 \%$ ). Our MP heuristic search yielded 28 trees of equal length (627 steps); each of the 28 trees had a consistency index (CI) of 0.892 and a retention index (RI) of 0.919 . Within the cpDNA phylogeny, Lepechinia flammea, L. glomerata, and L. nelsonii formed a well supported (ML BS $=100 \%$; MP BS $=100 \%$ ) clade (Figure 3). Within this clade, L. flammea and L. glomerata were recovered as sister taxa (ML $\mathrm{BS}=86 \%$; MP BS $=90 \%$ ). The clade composed of L. flammea, L. glomerata, and L. nelsonii was sister to L. calycina (Benth.) Epling ex Munz (ML BS = 79\%; MP BS =72\%), a species endemic to California. The clade of Lepechinia calycina, L. flammea, L. glomerata, and L. nelsonii was sister $(\mathrm{ML} \mathrm{BS}=96 \%$; MP BS $=92 \%)$ to a clade containing taxa that are also distributed in Mexico (except the South American L. meyenii).

After excluding 405 characters because of alignment ambiguity or long uninformative insertions (mostly involving Melissa), our nuclear gene region (nDNA) alignment was 3,193 nucleotides in length. The nDNA alignment contained 442 variable and 213 PI characters (6.7\%). In the MP analyses we recovered nine nDNA trees of equal length (866 steps), with each tree having a CI of 0.702 and an RI of 0.716. In the nDNA phylogeny, L. flammea, L. glomerata, and L. nelsonii once again formed a clade with $100 \%$ ML \& MP BS (Figure 4). At a single nucleotide position (173 in alignment) in the ITS1 region, Lepechinia nelsonii displayed a chromatogram double peak (Y) that was intermediate between L. glomerata (C) and L. flammea (T). In contrast to the cpDNA phylogeny, L. flammea and L. nelsonii were recovered as sister taxa $(\mathrm{MLBS}=71 \%$; $\mathrm{MPBS}=72 \%)$, and L. hastata (native to Baja California Sur and the remote Socorro Island) was recovered as sister to the aforementioned three species with weak support (ML BS $=72 \%$; MP BS = $58 \%$ ). These four taxa were part of a larger clade (ML BS = $100 \%$; MP BS $=100 \%$ ) that included the same taxa as in the cpDNA tree with the exception of L. calycina.

\section{Discussion}

The discovery of Lepechinia flammea and the rediscovery of L. glomerata (after 48 years without being collected) in Jalisco, demonstrates how critical botanical exploration is in the understanding of Mexican flora. For example, the populations of L. glomerata and L. flammea from Jalisco seem to be disjunct relative to the populations from Guerrero and Oaxaca, since they are separated by at least $600 \mathrm{~km}$. However, it is likely that these species will eventually be found in intermediate locations with similar ecological conditions if botanical exploration is conducted in the appropriate localities. Some places where these plants would be expected are Sierra de Cacoma and Sierra de Manantlán, Jalisco; Cerro Grande, Jalisco-Colima border; and Sierra de Coalcomán, Michoacán. The fact that Lepechinia flammea and L. glomerata are shrubby, odoriferous plants with distinctive leaves, inflorescences and flowers, further highlights the urgent need for increased botanical collection and study in Mexico: if distinctive plants such as these have gone undescribed/uncollected, the number of less obvious species awaiting discovery/collection could be staggering.

Although Lepechinia flammea, L. nelsonii, and L. glomerata were nested within a clade of mostly Mexican taxa in both the cpDNA and nDNA analyses, the sister lineage to these three taxa is decidedly unclear. In the cpDNA analyses, the California endemic L. calycina was recovered as sister, while L. hastata was the sister lineage in the nDNA analysis. Neither of these sister relationships were strongly supported, nor are there clear morphological connections 
that favors either scenario. On the basis of geography, $L$. hastata, which occurs in the southern tip of Baja California, would seem like a more plausible sister lineage candidate due to its current relative proximity and the fact that Baja California was once connected to mainland Mexico in the vicinity of present day localities of L. flammea, L. nelsonii, and L. glomerata. In the cpDNA phylogeny, however, $L$. hastata is deeply nested inside a clade of three morphologically and geographically dissimilar species. One possible explanation for the recovery of L. calycina as a sister lineage in the cpDNA analyses is ancient hybridization, especially given its position in the nDNA tree. The lack of BS support in the nDNA tree precludes us from making any conclusions regarding these data in regards to the potential sister lineage of L. flammea, L. nelsonii, and L. glomerata. We are hopeful that additional nuclear gene region data will eventually resolve this question.

The sister relationship between Lepechinia flammea and L. glomerata recovered in the cpDNA tree (Figure 3) is not surprising given the morphological and geographical similarities between the two species. Likewise, the close relationship between these two species and L. nelsonii is in general agreement with morphology and geography. However, the sister relationship between L. flammea and L. nelsonii in the nDNA tree (albeit only moderately supported) is somewhat surprising based on a priori expectations. The conflicting

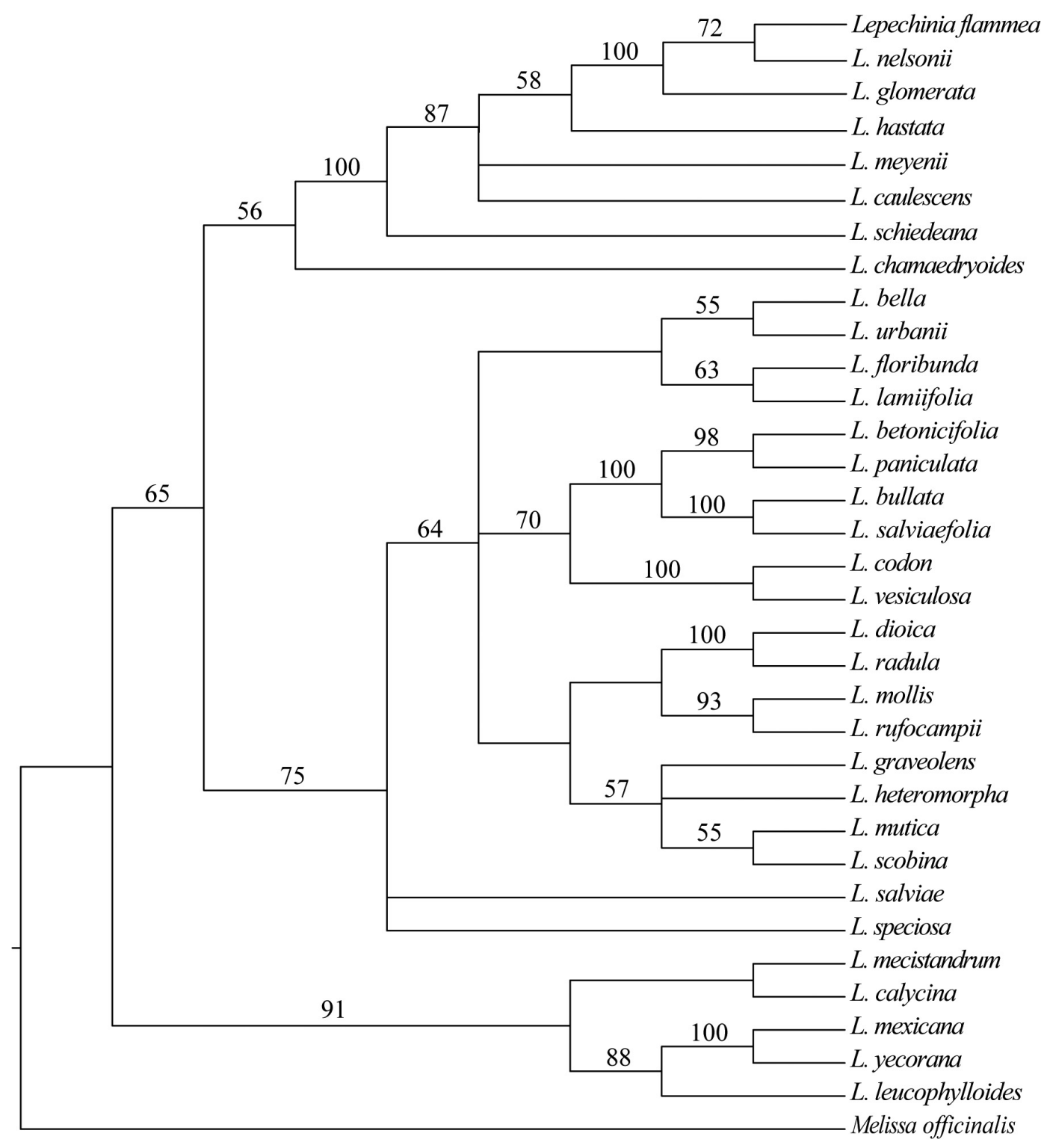

Figure 4. Maximum likelihood (ML) phylogram of Lepechinia obtained from an analysis of four concatenated nDNA sequences (ITS, ETS, GBSSI and PPR-AT3G09060). Bootstrap values higher than 50\% are shown above each branch. ML and MP bootstrap values above $70 \%$ are indicated near corresponding nodes. Focal taxa of this study are shown within black box. 
topologies between genetic compartments may be indicative of chloroplast capture or hybridization as has been suggested or documented for other core eudicots (Rieseberg and Soltis, 1991; Fehrer et al., 2007; Acosta and Premoli, 2010; Salmaki et al., 2013; Wang et al., 2013; Scheunert and Heubl, 2014; Wan et al., 2014), but this is unclear given our present limited sampling. The presence of a nucleotide polymorphism within the ITS sequence of L. nelsonii, that is intermediate between L. flammea and L. glomerata, also suggests that there may have been some recent genetic intermingling. Lepechinia nelsonii and L. flammea do share some morphological characters in common, however, to the exclusion of L. glomerata; the most obvious would be flower color (orange-red), and flower and leaf size (both larger than L. glomerata; Table 1).

If hybridization has led to speciation within these three taxa, the most likely scenario, based on morphological evidence, is that a hybridization event between L. nelsonii and L. glomerata gave rise to L. flammea. In this scenario, $L$. nelsonii would have been the pollen donor based on cpDNA results. Morphologically, L. flammea is intermediate in several characters relative to $L$. glomerata and $L$. nelsonii (Table 1). A strong argument against this scenario is: (1) $L$. glomerata and L. nelsonii typically occur at much different elevations (L. glomerata is found below, ca. 1,180 m, while
L. nelsonii occurs above $1,850 \mathrm{~m}$ ), (2) flower morphology suggests that L. glomerata might be pollinated by insects as opposed to hummingbirds as in L. nelsonii, and (3) L. nelsonii contains a double peak in the ITS sequence that we would expect in L. flammea, if L. glomerata and L. nelsonii had hybridized.

The similarity in flower color (and size) between Lepechinia nelsonii and L. flammea may be especially important because it could facilitate hybridization between the two species. Lepechinia nelsonii is hummingbird pollinated, and given the size and color of L. flammea it may be as well. If both are hummingbird pollinated, this could mean that hybridization could occur even if the two species were not in close proximity. Populations of these species in Jalisco are separated by less than $32 \mathrm{~km}$, and by about $131 \mathrm{~km}$ in Guerrero; if we consider that hummingbirds can reach speeds up to 12.4-14.4 $\mathrm{m} \mathrm{s}^{-1}$ (44.64-51.84 $\mathrm{km} \mathrm{hr}^{-1}$; Chai et al., 1999), and during migration travel from 32.1-36.2 km per day (Courter et al., 2013), the distances are not necessarily prohibitive in regard to pollen transfer. Furthermore, spatial or altitudinal movements in search of floral resources have been documented (Arizmendi and Ornelas, 1990; Gutiérrez et al., 2004; Partida et al., 2012) for some hummingbirds, as well as altitudinal moult-migration (Fraser et al., 2010). Hence, contact between L. flammea and L. nelsonii is feasi-

Table 1. Comparison of morphological characters, habitat, altitudinal range and distribution among Lepechinia g/omerata, $L$. flammea and $L$. nelsonii. ${ }^{*}=$ For this measurement, external floral bracts of the glomeruli were considered for $L$. glomerata and $L$. flammea, and most proximal floral bract to the pedicel for L. nelsonii.

\begin{tabular}{|c|c|c|c|}
\hline Character & L. glomerata & L. flammea & L. nelsonii \\
\hline Leaf shape & $\begin{array}{l}\text { lanceolate to slightly } \\
\text { elliptic-lanceolate }\end{array}$ & $\begin{array}{l}\text { elliptic to } \\
\text { elliptic-lanceolate }\end{array}$ & $\begin{array}{l}\text { lanceolate to narrow } \\
\text { elliptic-lanceolate }\end{array}$ \\
\hline Leaf size $(\mathrm{cm})$ & $(3.7-) 6.3-20 \times(1.3-) 2-3.9(-8.1)$ & $(3.9-) 12.7-23 \times(1.5-) 2.7-6.3$ & $15-26.5 \times(2.6-) 3-4.6$ \\
\hline Inflorescences & capituliform & capituliform & paniculate \\
\hline Floral bract size $(\mathrm{cm})^{*}$ & $1.5-2.9 \times 0.6-1.1$ & $0.9-1.7 \times(0.6-) 1-1.4$ & $0.9-1.6 \times 0.1-0.3$ \\
\hline Pedicel length (mm) & $0.8-1.3$ & $(0.8-) 1-2.3$ & $4-5(-10)$ \\
\hline Calyx tube size (mm) & $2.9-3.9 \times 3.2-3.5$ & $4.3-6.8 \times 4.2-6(-6.7)$ & $2.8-3.1(-3.8) \times(2.3-) 2.7-3.6$ \\
\hline Calyx teeth shape and size $(\mathrm{mm})$ & acuminate, $1.9-2.5$ & acuminate, (2.3-)3.5-5 & long aristate, (4.7-)6.7-7.4 \\
\hline Corolla color & blue to lavender & orange at base, and upwardly red & orange \\
\hline Corolla tube size $(\mathrm{mm})$ & $6.8-7.8 \times 2.3-3.4$ & $(10-) 12-16.5$ × 4.2-6.4(-7.8) & $14.2-16.5 \times 4.8-5.8$ \\
\hline Filament length (mm) & $8.4-8.9$ & $(13.6-) 16.4-18.7(-19.5)$ & $11.6-19.9$ \\
\hline Theca length (mm) & $0.5-1$ & $1-1.4(-1.7)$ & $1-1.2$ \\
\hline Style length (cm) & $1.1-1.4$ & $1.6-2.2$ & $(1.6-) 2-2.7$ \\
\hline Mericarp size (mm) & $2.5-2.9 \times 1.7-2.1$ & $(2.4-) 2.7-2.9 \times(1.6-) 1.8-2.2$ & $2.4-2.8 \times 1.4-2$ \\
\hline Habitat & $\begin{array}{l}\text { oak-pine forests and ecotones of } \\
\text { oak-pine/montane cloud forests }\end{array}$ & $\begin{array}{l}\text { montane cloud and } \\
\text { pine-oak forests }\end{array}$ & $\begin{array}{l}\text { pine, pine-oak and montane } \\
\text { cloud forests }\end{array}$ \\
\hline Altitudinal range (m) & $850-1,180$ & $2,000-2,700$ & $1,850-2,000(-2,600)$ \\
\hline Distribution & Guerrero and Jalisco & Guerrero and Jalisco & $\begin{array}{l}\text { Durango, Estado de México, } \\
\text { Guerrero, Jalisco, Michoacán } \\
\text { and Sinaloa }\end{array}$ \\
\hline
\end{tabular}


ble. However, more botanical exploration in proximal areas where these species grow and studies of their interaction with pollinators are needed to assess potential gene flow between species. It should be noted that occasional hybridization does not necessarily imply a hybrid origin for any of these species, but might explain the discordance between the cpDNA and nDNA observed here.

Another possibility that would be consistent with morphology is that incomplete lineage sorting among the nDNA gene regions has confounded our attempts to estimate the phylogeny of these three taxa in this instance. With our limited current sampling (and suboptimal support values) it is premature to reach any definitive conclusions regarding incomplete lineage sorting or hybridization at this point, but these questions will be addressed in a future study with additional sampling of accessions and gene regions. Future studies involving these taxa will also include samples of $L e$ pechinia flammea from Oaxaca, and will investigate pollination trends within L. nelsonii, L. flammea, and L. glomerata.

\section{Acknowledgments}

The facilities and attention of curators and colleagues of the herbaria consulted (E, ENCB, FCME, IBUG, IEB, M, MEXU, MICH, RSA, UAGC, UC, WIS and ZEA) are much appreciated. Financial support was partially provided by Universidad de Guadalajara and Consejo Nacional de Ciencia y Tecnología (CONACYT). We thank A. Castro-Castro, L.F. Colín-Nolasco, E. De Castro-Arce, M. Harker, L. Flores-Hernández, E. Suárez-Muro, R. Guerrero-Hernández, F.J. Santana-Michel, S. Templeton, N.I. Cacho, and J.A. Vázquez-García, for their contribution on fieldwork. Two anonymous reviewers and the editorial staff provided helpful comments that improved our manuscript. Part of this research was accomplished by means of an academic stay at University of Wisconsin-Madison at the Dr. K. Sytsma Lab, and supported by CONACYT.

\section{Literature cited}

Acosta M.C. and A.C. Premoli. 2010. Evidence of chloroplast capture in South American Nothofagus (subgenus Nothofagus, Nothofagaceae). Molecular Phylogenetics and Evolution 54:235-242.

Arizmendi M.C. and Ornelas J.F. 1990. Hummingbirds and their floral resources in a tropical dry forest in Mexico. Biotropica 22:172-180.

Chai P., Altshuler D.L., Stephens D.B. and Dillon M.E. 1999. Maximal horizontal flight performance of hummingbirds: effects of body mass and molt. Physiological and Biochemical Zoology 72:145-155.

Courter J.R., Johnson R.J., Bridges W.C. and Hubbard K.G. 2013. Assesing migration of ruby-throated hummingbirds (Arichilochus colubris) at broad spatial and temporal scales. The Auk 130:107-117.
Drew B.T. 2011. Phylogenetics and biogeography of Lepechinia (Lamiaceae), and evolutionary studies within the Mentheae tribe. Ph.D. Dissertation, University of Wisconsin, Madison. 249 pp.

Drew B.T. and Sytsma K.J. 2011. Testing the monophyly and placement of Lepechinia in the tribe Mentheae (Lamiaceae). Systematic Botany 36:1038-1049.

Drew B.T. and Sytsma K.J. 2013. The South American radiation of Lepechinia (Lamiaceae): phylogenetics, divergence times and evolution of dioecy. Botanical Journal of the Linnean Society 171:171-190.

Drew B.T., Cacho N.I. and Sytsma K.J. 2014. The transfer of two rare monotypic genera, Neoeplingia and Chaunostoma, to Lepechinia (Lamiaceae), and notes on their conservation. Taxon 63:831-842.

Epling C.C. 1926. Studies on the South American Labiatae. II. Synopsis of the genus Sphacele. Annals of the Missouri Botanical Garden 13:35-71.

Epling C. 1948. A synopsis of the tribe Lepechinieae (Labiatae). Brittonia 6:352-364.

Fehrer J., Gemeinholzer B., Chrtek J.Jr. and Bräutigam S. 2007. Incongruent plastid and nuclear DNA phylogenies reveal ancient intergeneric hybridization in Pilosella hawkweeds (Hieracium, Cichorieae, Asteraceae). Molecular Phylogenetics and Evolution 42:347-361.

Felsenstein J. 1985. Confidence limits on phylogenies: An approach using the bootstrap. Evolution 39:783-791.

Fraser K.C., Diamond A.W. and Chavarría L. 2010. Evidence of altitudinal moult-migration in a Central American hummingbird, Amazilia cyanura. Journal of Tropical Ecology 26:645-648.

Gutiérrez Z.A., Rojas-Nossa S.V. and Stiles F.G. 2004. Dinámica anual de la interacción colibrí-flor en ecosistemas altoandinos. Ornitologia Neotropical 15(Supl.):205-213.

Harley R.M., Atkins S., Budantsev A.L., Cantino P.D., Conn B.J., Grayer R., Harley M.M., de Kok R., Krestovskaja T., Morales R., Paton A.J., Ryding O. and Upson T. 2004. Labiatae. In: Kadereit J.W. Ed. The Families and Genera of Vascular Plants VII. Flowering Plants. Dicotyledons: Lamiales (except Acanthaceae including Avicenniaceae), pp. 167-275, Springer, Berlin.

Hart J.A. 1983. Systematic and evolutionary studies in the genus Lepechinia (Lamiaceae). Ph.D. Dissertation, Harvard University, Cambridge. 610 pp.

Lot A. and Chiang F. 1986. Manual de Herbario. Administración y Manejo de Colecciones, Técnicas de Recolección y Preparación de Ejemplares Botánicos. Consejo Nacional de la Flora de México, A.C., México, D.F.

Maddison D.R. and Maddison W.P. 2005. MacClade 4: Analysis of phylogeny and character evolution. Version 4.08. Sinauer Associates, Sunderland.

Martínez-Gordillo M. and Lozada-Pérez L. 2009. Una especie nueva de Lepechinia sección Glomeratae (Lamiaceae) de México. Brittonia 61:112-115.

Martínez-Gordillo M.J., Fragoso-Martínez I., García-Peña M.R. and Montiel O. 2013. Géneros de Lamiaceae de México, diversidad y endemismo. Revista Mexicana de Biodiversidad 84:30-86.

Moon H.K. 2012. A new synonym of Lepechinia (Salviinae: Lamiaceae). Phytotaxa 71:52.

Partida L.R., Enríquez P.L., Rangel-Salazar J.L., Lara C. and Martínez I.M. 2012. Abundancia de colibríes y uso de flores en un 
bosque templado del sureste de México. Revista de Biología Tropical 60:1621-1630.

Reynoso D.J.J., Hernández L.L., Ramírez D.R., Harker S.M., Cedano M.M. and Álvarez B.I.L. 2006. Catálogo preliminar de la flora vascular y micobiota del municipio de San Sebastián del Oeste, Jalisco, México. Ibugana 14:51-91.

Salmaki Y., Zarre S., Ryding O., Lindqvist C., Bräuchler C., Heubl G., Barber J. and Bendiksby M. 2013. Molecular phylogeny of tribe Stachydeae (Lamiaceae subfamily Lamioideae). Molecular Phylogenetics and Evolution 69:535-551.

Sánchez-González A. and González L.M. 2007. Técnicas de recolecta de plantas y herborización. In: Contreras-Ramos A., Cuevas C.C., Goyenechea I. and Iturbide U. Eds. La Sistemática, Base del Conocimiento de la Biodiversidad, pp. 123-133, Universidad Autónoma del Estado de Hidalgo, Pachuca.

Rieseberg L.H. and Soltis D.E. 1991. Phylogenetic consequences of cytoplasmic gene flow in plants. Evolutionary Trends in Plants 5:65-84.

Scheunert A. and Heubl G. 2014. Diversification of Scrophularia (Scrophulariaceae) in the western Mediterranean and Macaronesia - Phylogenetic relationships, reticulate evolution and biogeographic patterns. Molecular Phylogenetics and Evolution 70:296-313.

Swofford D.L. 2002. PAUP*: Phylogenetic analysis using par- simony (and other methods), version 4.0. Sinauer Associates, Sunderland.

Thiers B. 2014. Index Herbariorum: a global directory of public herbaria and associated staff. New York Botanical Garden's Virtual Herbarium. <sweetgum.nybg.org/ih/> (accessed January 31,2014$)$.

Turner B.L. 2013. A new species of Lepechinia (Lamiaceae) from Oaxaca, Mexico. Phytologia 95:138-140.

Walker J.B. and Sytsma K.J. 2007. Staminal evolution in the genus Salvia (Lamiaceae): molecular phylogenetic evidence for multiple origins of the staminal lever. Annals of Botany 100:375-391.

Wan D., Sun Y., Zhang X., Bai X., Wang J., Wang A. and Milne R. 2014. Multiple ITS copies reveal extensive hybridization within Rheum (Polygonaceae), a genus that has undergone rapid radiation. PloS ONE 9:e89769.

Wang Z.H., Peng H. and Kilian N. 2013. Molecular phylogeny of the Lactuca alliance (Cichorieae subtribe Lactucinae, Asteraceae) with focus on their Chinese centre of diversity detects potential events of reticulation and chloroplast capure. PloS ONE 8:e82692.

Zwickl D.J. 2006. Genetic algorithm approaches for the phylogenetic analysis of large biological sequence datasets under the maximum likelihood criterion. Ph.D. Dissertation, University of Texas, Austin, 115 pp.

Received: March 19th, 2014

Accepted: June 1st, 2014 
Appendix 1. Voucher information and GenBank accession numbers for taxa used in this study. Information is as follows: taxon name and authority, collecting locality, collector(s) name and collection number (herbarium), GenBank numbers for previously submitted loci (where applicable): ycf1 and ycf1-rp/15 spacer region, trnL-F, ITS, ETS, PPR-AT3G09060, and GBBSI, respectively. Abbreviations: IBUG = Herbario del Instituto de Botánica de Guadalajara, $M=$ Botanische Staatssammlung München, $M O=$ Herbarium from the Missouri Botanical Garden, RSABG = Rancho Santa Ana Botanical Garden, UCBG = UC-Berkeley Botanical Garden, WIS = Herbarium from the University of Wisconsin-Madison.

Lepechinia bella Epling, Bolivia, R. Jabaily s.n. (WIS); KF307566, KF307411, KF307436, KF307471, KF307358, KF307498;

Lepechinia betonicifolia (Lam.) Epling, Ecuador, B. Drew 224 (WIS); KF307567, KF307412, KF307437, KF307472, KF307359, KF307499;

Lepechinia bullata (Kunth) Epling, Ecuador, B. Drew 223 (WIS); KF307568, KF307413, KF307438, KF307473, KF307360, KF307500;

Lepechinia calycina (Benth.) Epling ex Munz, U.S.A., B. Drew 20 (WIS); KF307569, KF307414, KF307439, KF307474, KF307361, KF307501;

Lepechinia caulescens (Ortega) Epling, Mexico, B. Drew 149 (WIS); KF307570, KF307415, KF307440, KF307475, KF307362, KF307502;

Lepechinia chamaedryoides (Balb.) Epling, Chile, cultivated-RSABG, J. Walker 2537 (WIS); JF289031, AY570459, DQ667231, JF301317, KF307363, KF307503;

Lepechinia codon Epling, Peru, B. Drew 177 (WIS); KF307571, KF307416, KF307441, KF307476, KF307364, KF307504;

Lepechinia dioica J.A.Hart, Ecuador, B. Drew 232 (WIS); KF307572, KF307417, KF307442, KF307477, KF307365, KF307505;

Lepechinia floribunda (Benth.) Epling, Peru, B. Drew 172 (WIS); KF307573, KF307418, KF307443, KF307478, KF307367, KF307507;

Lepechinia ganderi Epling, U.S.A., B. Drew 24 (WIS); KF307574, KF30741, KF307444, KF307479, KF307366, KF307506:

Lepechinia flammea Mart.Gord. \& Lozada-Pérez, Mexico, B. Drew 155 (WIS; previously treated as L. glomerata Epling in Drew and Sytsma 2011, 2012, 2013); JF289032, JF301377, JF301346, JF301318; KF307368, KF307508;

L. glomerata Epling, Mexico, J.G. González-Gallegos et al. 947 (IBUG);

Lepechinia graveolens (Regel) Epling, Bolivia, Fuentes et al. 10351 (M); KF307575, KF307420, KF307445, KF307480, KF307369, KF307509;

Lepechinia hastata (A.Gray) Epling, Mexico, B. Drew 44 (WIS); JF289033, JF301378, JF301347, JF301319; KF307370, KF307510;

Lepechinia heteromorpha (Briq.) Epling, Peru, B. Drew192 (WIS); KF307576, KF307421, KF307446, KF307481, KF307371, KF307511;

Lepechinia lamiifolia (Benth.) Epling, Peru, B. Drew 178 (WIS); JF289034, JF301379, JF301348, JF301320; KF307372, KF307512;

Lepechinia (Neoeplingia) leucophylloides (Ramamoorthy, Hiriart \& Medrano) B.T.Drew, Cacho \& Sytsma, Mexico, B. Drew 129 (WIS); JF289047, JF301390, JF301354, JF301327, KF307391, KF307531;

Lepechinia (Chaunostoma) mecistandra (Donn.Sm.) H.K.Moon, El Salvador, J.A. Monterrosa \& R. A. Carballo 213 (MO); JF289005, JF301361, JF301342, JF301311, KF307357, KF307497;

Lepechinia mexicana (S.Schauer) Epling, Mexico, B. Drew 164 (WIS); JF289035, JF301380, JF301349, JF301321, KF307375, KF307515;

Lepechinia meyenii (Walp.) Epling, Peru, B. Drew 173 (WIS); KF307578, KF307423, KF307448, KF307483, KF307376, KF307516;

Lepechinia mollis Epling, Peru, B. Drew 182 (WIS); KF307579, KF307424, KF307449

KF307484, KF307377, KF307517;

Lepechinia mutica (Benth.) Epling, Ecuador, B. Drew 229 (WIS); KF307580, KF307425, KF307450, KF307485, KF307378, KF307518;

Lepechinia nelsonii (Fernald) Epling, Mexico, B. Drew 146 (WIS);

Lepechinia paniculata (Kunth) Epling, Ecuador, B. Drew 241 (WIS); KF307581, KF307426, KF307451, KF307486, KF307379, KF307519;

Lepechinia radula (Benth.) Epling, Ecuador, B. Drew 237 (WIS); KF307582, KF307427, KF307452, KF307487, KF307380, KF307520; 
Appendix 1. Continuation.

Lepechinia rufocampii Epling \& Mathias, Ecuador, B. Drew 245 (WIS); KF307583, KF307428, KF307453, KF307488, KF307381, KF307521;

Lepechinia salviae (Lindl.) Epling, Chile, R. Jabaily s.n. (WIS); KF307584, KF307429, KF307454, KF307489, KF307382, KF307522;

Lepechinia salviifolia (Kunth) Epling, Colombia, R. Jabaily s.n. (WIS); JF289038, JF301383, JF301352, JF301324, KF307383, KF307523;

Lepechinia schiedeana (Schltdl.) Vatke, Mexico, B. Drew 157 (WIS); KF307585, KF307430, KF307455, KF307490, KF307384, KF307524;

Lepechinia scobina Epling, Peru, B. Drew 184 (WIS); KF307586, KF307431, KF307456, KF307491, KF307385, KF307525;

Lepechinia speciosa (A.St.-Hil. ex Benth.) Epling, Brazil, Cordeno 3060 (WIS); KF307587, KF307432, KF307457, KF307492, KF307386, KF307526;

Lepechinia urbanii Epling, Dominican Republic, B. Drew 135 (WIS); KF307588, KF307433, KF307458, KF307493, KF307387, KF307527;

Lepechinia vesiculosa (Benth.) Epling, Peru, B. Drew 175 (WIS); KF307589, KF307434, KF307459, KF307494, KF307388, KF307528;

Lepechinia yecorana Henrickson, Fishbein, \& T.Van Devender, Mexico, Henrickson 24691 (WIS); KF307590, KF307435, KF307460, KF307495, KF307389, KF307529;

Melissa officinalis L., cultivated-UW-Madison, B. Drew 70 (WIS); JF289042, JF301386, JF301353, JF301325, KF307390, KF307530. 


\section{Appendix 2.}

Additional specimens examined of Lepechinia nelsonii. Mexico. Jalisco. Autlán de Navarro: Sierra de Manantlán, 3-4 km on way to Las Joyas W of La Cumbre (which is S of El Chante), 2,000 m, 7 Feb 1983, R. McVaugh 26589 (IBUG, MICH); 5-6 km al NE de Corralitos, camino a Ahuacapán, Corralitos, 1700 m, 27 Feb 1987, J.A. Vázquez-G. \& L. Guzmán-H. 4219 (ENCB, IEB, MEXU, WIS, ZEA); cañada de la Moza, 4 km adelante de Cuatro Caminos, 1940 m, 19 Dec 1992, R. Cuevas-G. \& L. Guzmán-H. 4497 (ENCB, ZEA). Cuautitlán de García Barragán: about 15 miles SE of Autlán, in mountains near trail from Chante to Rancho Manantlán and thence SE 3-4 hours with pack animals toward El Cuartón, 2400 m, 13 Apr 1949, R. McVaugh 10260 (MEXU, MICH); foothills of Sierra de Manantlán, 16-22 S of E Chante, 1,500 m, 3 Feb 1975, R. McVaugh 26118 (MICH); between Zarzamora (2 houses) and Las Joyas, ca. 6 km WSW of Rincón de Manantlán, ca. 15 km SSW of El Chante, 1900 m, 6 Jan 1979, H.H. Iltis et al. 1345 (ENCB, IBUG, MEXU, WIS); 6-8 km al E de Capillas por la brecha rumbo a Las Joyas, Sierra de Manantlán, 2320 m, 21 Jan 2011, J.G. González-G. \& F. J. Santana-Michel 849 (IBUG). Mazamitla: fraccionamiento Natura, Mazamitla, 2,000 m, 7 Jan 1996 , J.A. Machuca-N. 7723 (IBUG, IEB, MEXU, MICH). Talpa de Allende: 10-12 miles S of Talpa de Allende, in the headwaters of an E branch of Río de Talpa, 3 miles above Los Sauces, 1,400 m, 26 Nov 1960, R. McVaugh 21442 (MICH); headwaters of Río Mascota (20-25 km -airline-, SE of Talpa de Allende), 12-13 km above (S of) El Rincón, on the road to Aserradero La Cumbre, 1,700 m, 3 Apr 1965, R. McVaugh 23482 (ENCB, MICH). Tapalpa: NO de Tapalpa, aprox. 12 km por la brecha Tapalpa-Chiquilistlán, 2,100 m, 12 Mar 1989, A. Flores-M. et al. 1529 (IBUG). Tecalitlán: barranca La Resbalosa, 18 km al SE de Llanitos, 2,060 m, 28 Feb 1990, J. Villa-C. \& J. Chávez-L. 632 (IBUG, IEB, MICH); Sierra del Halo, cerca de San Isidro, 2,100 m, 10 Feb 1991 , CházaroB. M. J. \& J. A. Machuca-N. 6538 (IEB, MEXU, WIS). Tolimán: 3-4 km al S de La Laguna, camino a Cerro Grande, 2050 m, 31 Jan 1987, R. Cuevas-G. \& M. Rosales 1744 (MEXU, WIS, ZEA); $15.7 \mathrm{~km}$ by road N of El Terrero on the road to La Laguna, ca. $35.5 \mathrm{~km}$ (by air) due NW of Colima, ca. 38 km (air) WSW of Nevado de Colima, 2,113 m, 23 Mar 1989, M.A. Wetter et al. 2063 (MEXU, MICH, WIS, ZEA). Michoacán. Aguililla: NW of Aguililla, about 6-7 km S of Aserradero Dos Aguas, 2,000 m, 3 Mar 1965, R. McVaugh 22728 (MICH). Coalcomán: Coalcomán, 1,000 m, 5 Feb 1939, G.B. Hinton et al. 12947 (MICH). 